\title{
POUND IN MULTIPLE PERSPECTIVE
}


Also by Andrew Gibson and published by Macmillan

READING NARRATIVE DISCOURSE: Studies in the Novel from Cervantes to Beckett 


\title{
Pound in Multiple Perspective
}

\section{A Collection of Critical Essays}

\author{
Edited by
}

\author{
ANDREW GIBSON \\ Senior Lecturer in English \\ Royal Holloway and Bedford New College \\ University of London
}


Text (c) The Macmillan Press Ltd 1993

Editorial matter and selection (c) Andrew Gibson 1993

Softcover reprint of the hardcover 1st edition 1993

All rights reserved. No reproduction, copy or transmission of this publication may be made without written permission.

No paragraph of this publication may be reproduced, copied or transmitted save with written permission or in accordance with the provisions of the Copyright, Designs and Patents Act 1988, or under the terms of any licence permitting limited copying issued by the Copyright Licensing Agency, 90 Tottenham Court Road, London W1P 9HE.

Any person who does any unauthorised act in relation to this publication may be liable to criminal prosecution and civil claims for damages.

First published 1993 by

THE MACMILLAN PRESS LTD

Houndmills, Basingstoke, Hampshire RG21 2XS

and London

Companies and representatives

throughout the world

ISBN 978-1-349-11196-1

ISBN 978-1-349-11194-7 (eBook)

DOI 10.1007/978-1-349-11194-7

A catalogue record for this book is available from the British Library

Printed in Great Britain by Ipswich Book Company Ltd Ipswich, Suffolk 


\section{Contents}

List of Abbreviations vi

Notes on the Contributors vii

Introduction 1

Andrew Gibson

1 'What's left for me to do?': Pound, Browning and the Problem of Poetic Influence

John Woolford

2 The Unknown Masterpiece: Yeats and the Design of the Cantos

\section{Warwick Gould}

3 'Experiments in Modernity': Ford and Pound

R. G. Hampson

4 'Like a Mexith's renowned statue bristling with emblems': Masquerade, Anthropology, Yeats and Pound among Wyndham Lewis's Apes of God

Peter L. Caracciolo

5 Pound and Joyce: Ulysses, the Cantos and the Shapes of Cultures

\section{Andrew Gibson}

6 'These fragments you have shelved (shored)':

Pound, Eliot and The Waste Land

John Harwood

7 Pound, Whitman and the American Epic

Transmission

Eric Mottram 


\section{List of Abbreviations}

$A B C \quad A B C$ of Reading (London: Faber, 1951).

$C \quad$ The Cantos of Ezra Pound (London: Faber, 1987) fourth collected edition.

CEP Collected Early Poems of Ezra Pound, ed. M. J. King (London: Faber, 1977).

CSP Collected Shorter Poems of Ezra Pound (London: Faber, 1973).

EP/DS Ezra Pound and Dorothy Shakespear: Their Letters 1909-1914, ed. B. Ahearn (London: Faber, 1987).

LE Literary Essays of Ezra Pound, ed. with an introduction by T. S. Eliot (London: Faber, 1954).

P/F Pound/Ford: The Story of a Literary Friendship, ed. Brita Lindberg-Seyersted (London: Faber, 1982).

P/J Pound/Joyce: The Letters of Ezra Pound to James Joyce, with Pound's Essays on Joyce, ed. Forrest Read (New York: New Directions, 1967).

P/Z Pound/Zukofsky: The Selected Letters of Ezra Pound and Louis Zukofsky, ed. B. Ahearn (London: Faber, 1987).

SL Selected Letters of Ezra Pound, 1907-1941, ed. D. D. Paige (London: Faber, 1951).

SP Selected Prose 1909-1965, ed. with an introduction by William Cookson (London: Faber, 1973).

SR The Spirit of Romance (London: Peter Owen, rev. edn, 1952).

$T \quad$ The Translations of Ezra Pound, with an introduction by Hugh Kenner (London: Faber, 1953). 


\section{Notes on the Contributors}

Peter L. Caracciolo is Senior Lecturer in English at Royal Holloway and Bedford New College, University of London. His publications include essays on Sheridan Le Fanu in the Victorian appendix to Twentieth-Century Crime and Mystery Writers (1980), Michael Moorcock, in Twentieth-Century Science Fiction Writers (1981), Wyndham Lewis in Robert Fraser (ed.), Sir James Frazer and the Literary Imagination (1990); and articles on Wilkie Collins, Conrad, Pound, Lessing and Aldiss in various learned journals. He edited The Arabian Nights in English Literature (1988). He is founder and organiser of the Inter-University Wyndham Lewis Seminar, and is on the editorial committee of Enemy News.

Andrew Gibson is Senior Lecturer in English at Royal Holloway and Bedford New College, University of London. He is the author of Reading Narrative Discourse: Studies in the Novel from Cervantes to Beckett (1990). He has published numerous articles on modern English, Irish, American and French writers in a wide range of scholarly journals and collections of essays. He is founder and organiser of the London University Seminar for Research into Joyce's Ulysses. He is currently editing another collection of essays, on the 'Circe' episode in Ulysses. He also writes fiction for children (published by Faber and Faber).

Warwick Gould is Reader in English Literature at Royal Holloway and Bedford New College, University of London. He is the co-author (with Marjorie Reeves) of Joachim of Fiore and the Myth of the Eternal Evangel in the Nineteenth Century (1987) and co-editor (with Phillip L. Marcus and Michael J. Sidnell) of The Secret Rose, Stories by W. B. Yeats: A Variorum Edition (1981, second edition, revised and enlarged, 1992). He is working with collaborators on The Collected Letters of W. B. Yeats, volume II: 1896-1900, and two volumes in the new Macmillan Collected Edition of the Works of W. B. Yeats. He is editor of the Yeats Annual. 
R. G. Hampson is Lecturer in English at Royal Holloway and Bedford New College, University of London. He is the author of Joseph Conrad: Betrayal and Identity (1992). He has edited Conrad's Lord Jim and Victory and Kipling's Something of Myself for Penguin. He is an associate editor for the Cambridge edition of The Works of Joseph Conrad and editor of The Conradian. He has edited a collection of essays on New British Poetries (with Peter Barry) and is currently editing a collection of essays on Ford Madox Ford (with W. A. Davenport).

John Harwood is Reader in English at the Flinders University of South Australia. He is the author of Olivia Shakespear and W. B. Yeats, and a regular contributor to the Macmillan Yeats Annual. His The Mythology of Modernism: Eliot to Derrida will shortly be published by Macmillan.

Eric Mottram is Emeritus Professor of English and American Literature, King's College, University of London. His publications include scores of essays and articles, books and booklets on Faulkner, Rexroth, Ginsberg and Bowles. He is the author of William Burroughs: The Algebra of Need, Towards Design in Poetry and Blood on the Nash Ambassador: Investigations in American Culture. He co-edited The New British Poetry and has published over twenty volumes of poetry, recently including Selected Poems, Peace Projects and Brief Novels, Season of Monsters, Resistances and Estuaries. In 1992 he held the Mountjoy Fellowship in the Basil Bunting Poetry Centre, University of Durham, and the first Poetics Program Fellowship in the Department of English, State University of New York, Buffalo.

John Woolford taught at Cambridge University from 1969 to 1980 and has been lecturing since then at King's College, University of London. He is the author of Browning the Revisionary (1988), and (with Daniel Karlin) is editing Browning's poems in the Longman Annotated English Poets Series. The first two v ulumes of this edition appeared in 1991. He has also published numerous articles on Romantic and Victorian poetry in various scholarly journals and collections of essays. He is presently working with S. M. Adamson on a chapter on literary language from 1776 to the present day (to be published by Cambridge University Press). 